\title{
NUTRITIONAL STATUS OF BALI RUGBY TEAM ATHLETES PREPARING FOR PON PAPUA 2021
}

\author{
I Putu Agus Dharma Hita ${ }^{1 *}$, B.M. Wara Kushartanti ${ }^{1}$, Doni Pranata ${ }^{1}$, Widiyanto ${ }^{1}$ \\ ${ }^{1}$ Ilmu Keolahragaan, Fakultas Ilmu Keolahragaan, Universitas Negeri Yogyakarta, Jl. Colombo No. 1, \\ Karangmalang, Depok, Sleman, Daerah Istimewa Yogyakarta, Indonesia. \\ putuagusdharma@yahoo.com,bm_warakushartanti@uny.ac.id,donipranata.2020@student.uny.ac.id, \\ widi@uny.ac.id
}

\begin{abstract}
Nutritional status is an important factor in maintaining body immunity. Poor nutritional status is one of the causes of degenerative diseases caused by a damaged lifestyle. This study aims to determine the nutritional status of Bali Rugby team athletes in preparation for the 2021 National Sports Week (PON) held in Papua Province. The type of research used is descriptive quantitative research with a survey method. The sample of this study was 14 athletes from the Bali Rugby Team, with an average age of 20 years. The data collected were height and weight and then analyzed using the Body Mass Index (BMI) formula. The results of this study are the average nutritional status of the Bali Rugby team athletes in preparation for PON Papua 2021, namely in the obesity category I, with details of the normal category as many as 5 athletes (35.7\%), overweight category as many as 3 athletes (21.4\%), and obesity category I as many as 6 athletes (42.9\%). The conclusion in this study is that the average nutritional status of Bali Rugby team athletes in preparation for the 2021 National Sports Week (PON) held in Papua Province shows that athletes are in the obesity category I. From these results, it is hoped that the coach can use it as information to face PON 2021. by evaluating a training program that is tailored to the condition of the athlete so that it can produce maximum performance in the Rugby sport in Bali Province.
\end{abstract}

Keywords: nutritional status, athlete, rugby, bali

\section{STATUS GIZI ATLET TIM RUGBY BALI PERSIAPAN PON PAPUA 2021}

\begin{abstract}
Abstrak
Status gizi merupakan salah satu faktor penting dalam menjaga imunitas tubuh. Status gizi yang buruk adalah salah satu penyebab timbulnya penyakit-penyakit degeneratif yang disebabkan oleh rusaknya gaya hidup. Penelitian ini bertujuan untuk mengetahui status gizi atlet tim Rugby Bali dalam persiapan Pekan Olahraga Nasional (PON) 2021 yang dilaksanakan di Provinsi Papua. Jenis penelitian yang digunakan yaitu penelitian deskriptif kuantitatif dengan metode survei. Sampel penelitian ini merupakan atlit Tim Rugby Bali yang berjumlah 14 orang wanita dengan rata-rata usia 20 tahun. Data yang terkumpul yaitu tinggi badan dan berat badan dan kemudian dianalisis menggunakan rumus Indeks Massa Tubuh (IMT). Hasil dari penelitian ini yaitu rata-rata kondisi status gizi atlet tim Rugby Bali dalam persiapan PON Papua 2021 yaitu dalam kategori obesitas I, dengan rincian kategori normal sebanyak 5 atlet (35,7\%), kategori overweight sebanyak 3 atlet (21,4\%), dan kategori obesitas I sebanyak 6 atlet $(42,9 \%)$. Kesimpulan dalam penelitian ini yaitu rata-rata status gizi atlet tim Rugby Bali dalam persiapan Pekan Olahraga Nasional (PON) 2021 yang dilaksanakan di Provinsi Papua menunjukan bahwa atlet termasuk kategori obesitas I. Dari hasil tersebut, diharapkan pelatih dapat menjadikannya sebagai informasi untuk menghadapi PON 2021 dengan cara mengevaluasi program latihan yang disesuaikan dengan kondisi atlet sehingga dapat menghasilkan prestasi yang maksimal pada cabang olahraga Rugby di Provinsi Bali.
\end{abstract}

Kata kunci: status gizi, atlet, rugby, bali 


\section{PENDAHULUAN}

Menghadapi PON papua 2021, keseluruhan tim cabang olahraga harus segera mempersiapkan diri untuk menyiapkan para atlet terbaiknya untuk berkompetisi melawan provinsi lainnya di indonesia. PON Papua 2021 merupakan salah satu contoh dari berbagai event yang ditunda karena pandemi COVID-19. Di dunia ada banyak event olahraga ditunda diakibatkan oleh pandemi COVID-19 salah satunya adalah event World Cup U-20 yang akan diselenggarakan di Indonesia pada tahun 2021 dan ditunda pada tahun 2023 mendatang. Banyak tertundanya event olahraga merupakan hasil suatu pertimbangan yang matang dari para stakeholder sebagai pemangku kebijakan, mengingat event ini akan memanfaatkan banyak orang dan atlet dalam proses penyelenggaraannya. Sedangkan pada saat ini kondisi di Indonesia bahkan dunia masih belum kondusif, hal ini juga didasarkan oleh wabah baru virus corona SARS-CoV-2 (penyakit coronavirus 2019 sebelumnya 2019-nCoV), yang berpusat di Provinsi Hubei Republik Rakyat Cina dan telah menyebar ke banyak negara lain. Pada 30 Januari 2020, Komite Darurat WHO mengumumkan keadaan darurat kesehatan global berdasarkan tingkat pemberitahuan kasus yang terus meningkat di Cina dan lokasi internasional (Velavan \& Meyer, 2020)

PON Papua 2021 diikuti oleh seluruh Provinsi di indonesia dan diselenggrakan melalui beberapa cabang olahraga. Provinsi Bali merupakan salah satu provinsi di Indonesia yang mengikuti event tersebut dan salah satu cabang olahraga yang diikuti adalah cabang olahraga Rugby. Rugby adalah permainan taktis dimana banyak pola yang direncanakan dalam bermain, walaupun pemain yang memiliki keterampilan tinggi bisa mendominasi pada kondisi tertentu, seorang pemain rugby harus saling bergantung pada setiap anggota tim untuk menciptakan permainan yang solid dan membuat keputusan yang tepat. Dalam segala hal, keberhasilan tim tergantung pada pemain yang bekerja dalam kombinasi (Harahap et al., 2019).

Rugby adalah olahraga yang dapat mengambil manfaat dari berbagai efek kesehatan, kebugaran dan kesenangan. Pertandingan rugby dicirikan oleh lari intensitas tinggi yang diselingi dengan pertarungan dengan aktivitas rendah. Beberapa perubahan arah dan keterampilan teknis, kekuatan dan keterampilan juga merupakan persyaratan utama, terutama ketika pemain terlibat dalam tekel, scrum, rucks, dan maul (Ranchordas et al., 2019). Sedangkan menurut Lynch et al., 2019 rugby adalah permainan yang dapat menguasai wilayah dengan memajukan bola ke arah garis lawan. Untuk mencegah kemajuan tim penyerang atau tim pembawa bola dan tim yang bertahan akan menangani pemain yang membawa bola.

Cabang olahraga Rugby pada PON Papua 2021 merupakan event yang kedua kali diikuti oleh provinsi Bali, setelah PON XIX tahun 2016 mengikuti event yang bertemakan eksebisi dan tergabung dengan Provinsi Banten, DI Yogyakarta, DKI Jakarta, Jawa Barat, Kalimantan Timur dan Papua. Juara cabang olahraga pada saat itu dimenangkan oleh Provinsi Papua, dengan perolehan 2 medali emas. Berdasarkan hasil perolehan medali tersebut provinsi Bali terus berbenah untuk dapat berprestasi pada event selanjutnya pada PON Papua 2021 nantinya. Namun sama halnya dengan provinsi lain, jajaran pelatih dan induk organisasi harus mempunyai cara-cara terbaik untuk mensiasati keadaan seperti sekarang ini. Sama halnya yang kita ketahui, kendala tersebut adalah pandemi COVID-19. Ada banyak kegiatan dan persiapan yang harus diubah, bahkan program latihan yang telah dibuat oleh pelatih dan telah direncanakan lama sebelumnya harus diubah, semua program terhenti dan atlet tidak bisa dikumpulkan untuk mengikuti latihan. Semua atlet diharuskan untuk latihan secara mandiri di rumah masing-masing, hal ini didasarkan oleh kebijakan pemerintah untuk melakukan pembatasan skala besar (PSBB) dan kebijakan lockdown di beberapa daerah. Lockdown dan PSBB merupakan suatu metode untuk membatasi pergerakan masyarkat agar tidak terpapar virus COVID-19, dan menekan laju penyebaran virus tersebut. Dengan demikian pelatih tidak bisa sepenuhnya mengontrol porsi latihan dan gizi atlet. 
Gizi merupakan salah satu faktor pendukung bagi para atlet, karena gizi adalah substansi makanan yang dibutuhkan tubuh untuk hidup sehat terdiri dari karbohidrat, protein, lemak, vitamin, dan mineral, gizi tersebut didalam tubuh berfungsi sebagai sumber energi untuk melakukan aktivitas tubuh (Pane et al., 2020). Gizi diperlukan mengingat cabang olahraga Rugby merupakan cabang olahraga yang tergolong keras dan diharuskan untuk melakukan kontak fisik antar pemain, hal ini didukung oleh pendapat Maemun et al., 2019 yaitu Rugby adalah olahraga yang memerlukan status hidrasi yang baik, dibutuhkan konsentrasi (menyusun strategi bermain), kebugaran fisik (tidak cepat lelah), kekuatan (rugby termasuk olahraga yang keras), ketahanan dan tenaga, dan juga proses pemulihan (recovery) yang cepat. Permainan dalam Rugby terbagi dalam tiga jenis permainan yang pertama regu yang terdapat 14 orang orang, yang kedua regu yang terdapat 11 orang dan yang ketiga regu yang terdapat 8 orang. Tetapi untuk yang diminati atau dominan untuk dimainkan ialah rugby dengan 11 orang pemain dan 8 orang pemain (Badrus Barnaman, 2020). Cabang olahraga Rugby memerlukan beberapa biomotor fisik diantaranya adalah power otot lengan, koordinasi mata tangan, akurasi passing rugby (Harahap et al., 2019). Dengan banyaknya biomotor yang diperlukan, atlet Rugby diharuskan untuk menjaga asupan gizi yang berguna untuk mendukung daya tahan dan stamina atlet tersebut. Gizi yang baik akan menghasilkan SDM yang berkualitas yaitu sehat, cerdas dan memiliki fisik yang tangguh serta produktif (Pahlev, 2012).

Status gizi merupakan salah satu faktor penting dalam menjaga imunitas tubuh. Status gizi yang buruk adalah salah satu penyebab timbulnya penyakit-penyakit degeneratif yang disebabkan oleh rusaknya gaya hidup. Status gizi erat kaitannya dengan individu atlet, karena status gizi seorang atlet didasarkan terhadap apa saja yang mereka konsumsi setiap hari pra latihan maupun pasca latihan. Hita et al., 2020 menyatakan bahwa tatus gizi ialah suatu keadaan tubuh yang merupakan cerminan dari apa yang kita konsumsi setiap harinya. Status gizi dikatakan baik apalagi kalori yang masuk kedalam tubuh melalui apa yang kita makan seimbang dengan kalori yang keluar melalui aktivitas yang kita lakukan. Pada penelitian ini bertujuan untuk melihat bagaimana status gizi atlet tim rugby Bali persiapan PON Papua 2021, Hasil penelitian diharapkan dapat digunakan untuk memberikan informasi kepada staf pelatih dan jajarannya dalam memberikan evaluasi dan kebijakan selanjutnya dalam menghadapi PON 2021.

\section{METODE}

Jenis penelitian yang digunakan dalam penelitian ini merupakan penelitian deskriptif kuantitatif dengan metode survey. Menurut Sandu Siyoto dan Ali Sodik, 2015 metode survei merupakan metode penelitian yang menggunakan kuesioner sebagai instrumen utama untuk mengumpulkan data. Penelitian ini dilakukan di Provinsi Bali pada bulan Desember tahun 2020. Sampel dalam penelitian ini berjumlah 14 orang wanita yang merupakan atlet tim Rugby Bali dalam persiapan Pekan Olahraga Nasional (PON) tahun 2021 di Provinsi Papua.

Status gizi diukur menggunakan teknik indeks massa tubuh (IMT) dengan cara mengetahui berat badan dan tinggi badan kemudia menggunakan rumus sebagai berikut:

$$
\frac{\text { Berat Badan }(\mathrm{kg})}{\text { Tinggi Badan }\left(\mathrm{m}^{2}\right)}
$$

Menurut P2PTM, 2018 klasifikasi kategori status gizi berdasarkan pengukuran IMT dapat dibagi menjadi beberapa kelompok, yaitu disajikan pada tabel 1 sebagai berikut: 
MEDIKORA, Vol. 20 No. 1 April 2021 - 68

I Putu Agus Dharma Hita, B.M. Wara Kushartanti, Doni Pranata, Widiyanto

Tabel 1. Kategori IMT Berdasarkan Kriteria Asia Pasifik WHO Tahun 2000

\begin{tabular}{ccc}
\hline No. & Kategori & IMT \\
\hline 1. & Underweight & $<18,5 \mathrm{~kg} / \mathrm{m}^{2}$ \\
2. & Normal & $18,5-22,9 \mathrm{~kg} / \mathrm{m}^{2}$ \\
3. & Overweight & $23-24,9 \mathrm{~kg} / \mathrm{m}^{2}$ \\
4. & Obesitas I & $25-29,9 \mathrm{~kg} / \mathrm{m}^{2}$ \\
5. & Obesitas II & $>30 \mathrm{~kg} / \mathrm{m}^{2}$ \\
\hline
\end{tabular}

\section{HASIL DAN PEMBAHASAN}

Berdasarkan data yang terkumpul, kemudian dianalisis dan didapatkan hasil distribusi frekuensi status gizi yaitu sebagai berikut:

Tabel 2. Distribusi Frekuensi Status Gizi

\begin{tabular}{|c|c|c|c|c|c|c|}
\hline \multirow[b]{2}{*}{ No. } & & & \multicolumn{4}{|c|}{ Status Gizi } \\
\hline & & & Frequency & Percent & $\begin{array}{c}\text { Valid } \\
\text { Percent }\end{array}$ & $\begin{array}{c}\text { Cumulative } \\
\text { Percent }\end{array}$ \\
\hline \multirow{4}{*}{1.} & & Normal & 5 & 35.7 & 35.7 & 35.7 \\
\hline & Valid & Overweight & 3 & 21.4 & 21.4 & 57.1 \\
\hline & & Obesitas I & 6 & 42.9 & 42.9 & 100.0 \\
\hline & To & tal & 14 & 100.0 & 100.0 & \\
\hline
\end{tabular}

Berdasarkan tabel distribusi frekuensi status gizi diatas, didapatkan hasil yaitu kategori normal sebanyak 5 atlet $(35,7 \%)$, kategori overweight sebanyak 3 atlet $(21,4 \%)$, dan kategori obesitas I sebanyak 6 atlet (42,9\%). Maka dapat disimpulkan jika sebagian besar status gizi atlet tim Rugby Bali dalam persiapan Pekan Olahraga Nasional (PON) 2021 yaitu dalam kategori obesitas I.

\section{PEMBAHASAN}

Pada penelitian ini presentase atlet rugby memiliki indeks massa tubuh yang berada pada kategori obesitas sebesar $(74,3 \%)$. Komposisi tubuh adalah susunan tubuh yang terdiri dari masa tubuh dan lemak. Apabila aktivitas lebih kurang dibandingkan asupan makanan, maka dapat terjadi penambahan lemak. Bagi altet, hal ini merupakan suatu faktor yang krusial karena berat badan sangat berhubungan dengan kekuatan, kecepatan, ketangkasan, penampilan dan ketahanan (Penggalih and Huriyati, 2013).

Berlawanan dengan stigma bahwa atlet memiliki gaya hidup yang lebih sehat serta lebih aktif secara fisik, prevalensi obesitas pada kalangan atlet cukup tinggi. Pada penelitian oleh Stiefel et al di Mississipi, Amerika Serikat, didapatkan bahwa selama 30 tahun terakhir telah terjadi peningkatan prevalensi obesitas pada usia anak dan remaja serta hubungannya dengan permasalahan kesehatan di usia dewasa seperti diabetes dan hipertensi. Hal ini dipersulit dengan kesulitan dalam mengidentifikasi obesitas. Pada penelitian oleh O'Brien et al, pada atlet berusia dewasa dan anak yang menjalani pemeriksaan rutin hanya $23 \%$ yang didiagnosis mengalami obesitas dan hanya 33\% yang benar-benar menjalani perubahan gaya hidup seperti berolahraga teratur dan pola makan (Griffin et al., 2016).

Kebugaran jasmani sangat berhubungan dengan status gizi. Kemampuan atlet dalam menyesuaikan fungsi terhadap tugas jasmani tertentu dan keadaan lingkungan secara efisien sangat dipengaruhi oleh status gizi (Hidayat \& Suroto, 2017). Asupan makanan yang mengandung gizi yang diperlukan oleh tubuh menentukan kebugaran jasmani seseorang. 
Apabila status gizi tidak normal misalnya pada kegemukan maka tubuh akan sulit bergerak dan tentu saja akan mempengaruhi performa atlet.

Faktor penyebab obesitas terdiri dari banyak faktor, antara lain konsumsi makanan tinggi gula seperti makanan cepat saji, kurangnya aktivitas fisik, faktor psikologis, usia, jenis klemain dan faktor genetic (Kurdanti et al., 2015). Pada massa pandeim ini, seluruh atlet diharuskan untuk latihan secara mandiri di rumah masing-masing akibat kebijakan lockdown. Adanya kebijakan lockdown sangat berpengaruh terhadap masalah kesehatan atlet, khususnya psikologis, gizi, mental, hingga penurunan kekuatan dan masa otot. Khususnya ketika kompetisi olah raga semuanya harus ditiadakan selama masa pandemi (Paramita et al., 2021).

Selama masa pandemi, memang kegiatan pelatihan tetap dipandu oleh pelatih dari jarak jauh. Namun, sarana pelatihan fisik yang terbatas selama di rumah sangat mempengaruhi intensitas latihan fisik atlet. Dalam pengawasan pelatih secara langsung gaya hidup atlet dapat dikontrol. Salah satunya dalam pemilihan jenis makanan serta minuman yang dikonsumsi. Pola makan untuk atlet dapat dipenuhi dalam tiga kali makan sehari. Asupan makanan tinggi protein dan karbohidrat diutamakan untuk menunjang kekuatn otot atlet dan mengoptimalkan stamina. Makanan yang tinggi lemak dihindari karena selain dapat menyebabkan obesitas, makanan tinggi lemak dapat meningkatkan resiko penyakit jantung koroner, stroke dan kanker (Penggalih and Huriyati, 2013). Pada masa pandemi tidak adanya kontrol asupan makanan serta motivasi yang menurun akibat ditiadakannya berbagai pertandingan dapat menyebabkan stres eating/binge eating pada atlet sehingga mengakibatkan obesitas (Roring et al., 2020).

Obestias pada atlet telah menjadi permasalahan yang menjadi perhatian pada 10-15 tahun terakhir. Pada penelitian oleh Griffin et al mengenai obesitas di antara telet sepaok bola, 25\% atlet sepak bola di North Carolina Amerika Serikat mengalam obesitas. Komposisi tubuh tidak dapat memprediksi keberhasilan dalam berolahraga, tapi dapat mempengaruhi performa yang optimal pada cabang olah raga tertentu. Pada cabang olah raga seperti pelari jarak jauh, pesepeda atau pemain basket memerlukan daya tahan tubuh yang tinggi serta keseimbangan kekuatan. Hal ini menyebabkan adanya lemak yang berlebih akan mengganggu performa (Griffin et al., 2016).

Obesitas dapat meningkatkan resiko terjadinya berbagai permasalahan kesehatan pada atlet seperti gangguan tidur, hipertensi, arteroskleotirk, sindrom metabolik, osteoartritis dan peningkatan resiko cidera (Griffin et al., 2016). Sebuah penelitian menunjukkan pada altet berusia muda, mereka yang memiliki indeks massa tubuh lebih dari $35 \mathrm{~kg} / \mathrm{m}^{2}$ memiliki faktor resiko penyakit kardiovaskular yang lebih tinggi. Pada penelitian ini, atlet dengan indeks masa tubuh yang tinggi juga menjalani pemeriksaan persentase lemak tubuh. Atlet dengan indeks massa tubuh yang tinggi serta indeks lmeak tubuh yang tinggi memiliki faktor komorbid untuk terinfeksi virus Covid-19 (Lighter et al., 2020).

Untuk mendeteksi obesitas, status gizi yang diukur dengan menggunakan indeks massa tubuh menunjukkan hasil yang bervariasi apabila dilihat hubungannya dengan variabel lain sseperti ktingkat kebugaran jasmani atau kekuatan otot. Hal ini dikarenakan pada indeks masa tubuh hanya menggunakan indikator berat badan dan tinggi badan, serta tidak memperhitungakn faktor lain yang dapat mempengaruhi berat badan seperti kepadatan tulang dan massa otot (Singh Dhapola \& Verma, 2017). Beberapa ahli kedokteran olah raga masih mempertimabangkan kevalidan penggunaan indeks massa tubuh sebagai parameter 'berat badan yang aman' bagi atlet.

Penelitian oleh Siregar dan Dani (2018) menggunakan persen lemak tubuh dengan alat skinfold caliper-thickness. Hasil penelitian menunjukkan $75 \%$ atlet memiliki standar kecukupan energi pada kategori sedang. Peneliti menyatakan kelebihan berat badan tidak akan menimbulkan permasalahan jika kadar lemak tubuh masih dalam batas normal. Pada atlet tertentu, kelebihan berat badan yang hanya ditinjau dari indeks massa tubuh seringd ijumpai 
tetapi tidak mempengaruhi performa di lapangan. Berat badan ideal atlet sekarang tidak dilihat berdasarkan perbandinbannya dnegan tinggi badan, teatpi lebih dilihat dari tebal lemak di bawah kulit (Siregar \& Lasar Dani, 2019).

Menurut Wibowo and Hakim, 2019 meneliti tentang indeks massa tubuh di antara atlet rugby Terdapat 28 atlet rugby dengan hasil penggolongan IMT dengan nilai Min 19,25 kategori normal dan nilai Max 20,58 kategori normal. Nilai rata-rata IMT cabor rugby 24,56 dengan kategori kelebihan ringan. Penelitian ini juga menggunakan lingkar pinggang sebagai parameter untuk mengukur resiko gangguan kesehatan. Hal ini menunjukkan bahwa indeks massa tubuh bukan parameter yang cukup akurat untuk menentukan kategori status gizi (Wibowo and Hakim, 2019).

Massa tubuh pemain rugby di Amerika Serikat mengalami peningkatan secara signifikan selama 20 tahun terakhir. Hal ini disebabkan pola pelathian yang berbeda serta penempatan regimen, perubahan nutrisi seta persepsi bahwa atlet dengan postur tubuh yang lebih besar adlaah atlet yang memiliki performa lebih baik di lapangan, tidak semata-mata karena epidemi obesitas di masyarakat Amerika Serikat. Kekuatan meningkatkan fungsi dari massa tubuh dan hukum fisika menyatakan massa yang lebih besar lebih sulit untuk digerakkan. Oleh sebab itu bagi pemain rugby yang menempati posisi linemen, peningaktan massa tubuh justru suatu keuntungan.

Remaja yang berotot atau bertulang besar, umumnya memiliki nilai indeks massa tubuh yang lebih tinggi walau tidak disertai dengan jumlah lemak tubuh yang lebih tinggi. Hal ini semakin menguatkan pendapat bahwa pengukuran indesk massa tubuh tidak tepat dalam mengkategorikan status gizi. Pengukuran persen lemak tubuh tetap diperlukan dalam memperkuat justifikasi status gizi (Widyastuti \& Rosidi, 2018).

Penelitian lain oleh Pradana, 2020 menunjukkan bahwa nilai lemak viseral berkorelasi positif dengan indesk massa tubuh. Secara teoritis, lemak viseral adlaah komponen tubuh manusia yang dapat mempengaruhi berat badan tubuh. Walau demikian, berbeda dengan penelitian-penelitian lain, populasi pada penelitian ini adalah mahsiswa dengan aktivitas fisik yang tidak sama dengan atlet. Ditambah lagi pada penelitian ini, didapatkan juga hubungan yang signifkan antara kebiasaan konsumsi makanan berlemak tinggi dengan nilai lemak viseral. Kebiasaan konsumsi makanan berlemak tinggi hanya dinilai dari frekuensinya saja dan tidak diukur dari besarnya kontribusi energi dari makanan berlemak yang dikonsumsi oleh subjek penelitian sehingga hasil yang diperoleh masih rancu (Archilona, 2014).

Sebagaimana telah dipaparkan di atas, penelitian ini memiliki berbagai keterbatasan antara lain hanya satu variabel saja yang diukur yaitu indeks massa tubuh. Variabel lain seperti indeks lipatan lemak bawah kulit atau lingkar pinggang-banding pinggul (waist hip ratio) tidak diukur. Selain itu, meskipun hasil penelitian menunjukkan mayoritas subjek penelitian memiliki indeks massa tubuh pada kategori obesitas, tapi tidak dilakukan penelitian mengenai ketahanan fisik atlet rugby. Pada penelitian selanjutnya, variabel-variabel yang dapat menerangkan lebih jelas mengenai kesehatan fisik atlet perlu diteliti beserta parameter untuk mengukur ketahanan fisik atlet.

\section{SIMPULAN}

Hasil penelitian ini menunujukan bahwa sebagian besar gizi atlet tim Rugby Bali dalam persiapan Pekan Olahraga Nasional (PON) 2021 yang akan dilaksanakan di Provinsi Papua adalah menunjukan bahwa atlet termasuk kategori obesitas tingkat I, Hasil penelitian ini, diharapkan dapat dijadikan sebagai bahan informasi bagi pelatih untuk menghadapi PON 2021 dalam mengevaluasi program latihan yang disesuaikan dengan kondisi gizi atlet sehingga dapat menghasilkan prestasi yang maksimal pada cabang olahraga Rugby di Provinsi Bali dan melalui hasil penelitian ini pelatih dapat mengetahui informasi status gizi atlet selama masa pandemi 
COVID-19 dikarenakan selama masa pandemi COVID-19 atlet tidak menjalani latihan sesuai dengan program latihan hal ini dikarenakan keterbatasan gerak diakibatkan pandemi COVID19.

\section{DAFTAR PUSTAKA}

Archilona, Z. Y. (2014). Hubungan Antara Indeks Massa Tubuh dan Lemak Tubuh (Studi Kasus Pada Mahasiswa Kedokteran UNDIP). Jurnal Media Medika Muda, 3(1), 6-15.

Badrus Barnaman, M. (2020). Survei Minat Siswa Terhadap Olahraga Rugby Di Sma Negeri Se-Kecamatan Jombang. Jurnal Pendidikan Olahraga Dan Kesehatan, 8(1), 145-149.

Griffin, J. R., Maxwell, T. M., \& Griffin, L. (2016). The prevalence and consequences of obesity in athletes. Current Orthopaedic Practice, 27(2), 129-134. https://doi.org/10.1097/BCO.0000000000000346

Harahap, A. S., Barata, I., \& Apriyanto, T. (2019). Hubungan Antara Power Otot Lengan Dan Koordinasi Mata Tangan Dengan Akurasi Passing Rugby Universitas Negeri Jakarta. Jurnal Ilmiah Sport Coaching and Education, 3(2), 154-163.

Hidayat, A., \& Suroto. (2017). Hubungan Antara Status Gizi Dan Aktivitas Fisik Dengan Tingkat Kebugaran Jasmani Siswa. Jurnal Pendidikan Olahraga Dan Kesehatan, 4(2), 516-521.

Hita, I. P. A. D., Kushartanti, B. M. W., \& Nanda, F. A. (2020). Physical Activity, Nutritional Status, Basal Metabolic Rate, and Total Energy Expenditure of Indonesia Migrant Workers during Covid-19 Pandemic. Jurnal Pendidikan Jasmani Dan Olahraga, 5(2), 122-128. https://doi.org/https://doi.org/10.17509/jpjo.v5i2.26791

Kurdanti, W., Suryani, I., Syamsiatun, N. H., Siwi, L. P., Adityanti, M. M., Mustikaningsih, D., \& Sholihah, K. I. (2015). Faktor-faktor yang mempengaruhi kejadian obesitas pada remaja. Jurnal Gizi Klinik Indonesia, 11(4), 179. https://doi.org/10.22146/ijen.22900

Lighter, J., Phillips, M., Hochman, S., Sterling, S., Johnson, D., Francois, F., \& Stachel, A. (2020). Obesity in patients younger than 60 years is a risk factor for COVID-19 hospital admission. Clinical Infectious Diseases, 71(15), 896-897. https://doi.org/10.1093/cid/ciaa415

Maemun, P., Kuswari, M., \& Jus'at, I. (2019). Pengetahuan Tentang Cairan, Asupan Cairan, Status Hidrasi, dan Tingkat Kebugaran pada Atlet Rugby di Universitas Negeri Jakarta.

P2PTM. (2018). Klasifikasi Obesitas Setelah Pengukuran IMT. Kementerian Kesehatan RI.

Pahlev, A. E. (2012). Determinan Status Gizi Pada Siswa Sekolah Dasar. Jurnal Kesehatan Masyarakat, 7(2), 122-126. https://doi.org/10.15294/kemas.v7i2.2807

Pane, H. W., Tasnim, T., Sulfianti, S., Hasnidar, H., Puspita, R., Hastuti, P., Apriza, A., Pattola, P., Sianturi, E., \& Rifai, A. (2020). Gizi dan Kesehatan. Yayasan Kita Menulis.

Paramita, B. L., Ayuningtyas, D., Cibubur, K., Ciracas, K., \& Timur, J. (2021). Athlete 's Health Maintanance Management during a Pandemic Covid -19: A Case Study at a 
MEDIKORA, Vol. 20 No. 1 April 2021 - 72

I Putu Agus Dharma Hita, B.M. Wara Kushartanti, Doni Pranata, Widiyanto

National Sport Hospital Manajemen Pemeliharaan Kesehatan Atlet selama Pandemi Covid - 19: Studi Kasus di Rumah Sakit Olahraga Nasional. 17(1), 19-31.

Penggalih, M.H.S.T. and Huriyati, E., 2013. Gaya Hidup , Status Gizi Dan Stamina Atlet. 23(4), pp.192-199.

Pradana, G., 2020. Hubungan antara stres psikologis dengan gizi lebih pada siswa kelas sembilan. Skripsi-2016.

Ranchordas, M. K., Pratt, H., Parsons, M., Parry, A., Boyd, C., \& Lynn, A. (2019). Effect of caffeinated gum on a battery of rugby-specific tests in trained university-standard male rugby union players. Journal of the International Society of Sports Nutrition, 16(1), 1-9.

Roring, N. M., Posangi, J., \& Manampiring, A. E. (2020). Hubungan antara pengetahuan gizi, aktivitas fisik, dan intensitas olahraga dengan status gizi. Jurnal Biomedik: Jbm, 12(2), 110-116. https://doi.org/10.35790/jbm.12.2.2020.29442

Sandu Siyoto dan Ali Sodik. (2015). Dasar Metodologi Penelitian.

Singh Dhapola, M., \& Verma, B. (2017). 4(2): 313-315 Relationship of body mass index with agility and speed of university players. $313 \sim$ International Journal of Physical Education, Sports and Health, 4(2), 313-315.

Siregar, N. S., \& Lasar Dani, D. P. (2019). Hubungan Tingkat Kecukupan Energi Dengan Status Gizi Atlet Gulat Pplp Sumatera Utara. Sains Olahraga: Jurnal Ilmiah Ilmu Keolahragaan, 2(1), 10. https://doi.org/10.24114/so.v2i1.12871

Velavan, T. P., \& Meyer, C. G. (2020). The COVID-19 epidemic. Tropical Medicine and International Health, 25(3), 278-280. https://doi.org/10.1111/tmi.13383

Wibowo, E.T. and Hakim, A.A., 2019. Profil Indeks Massa Tubuh Pada Atlet Tim Nasional Indonesia Pada Asian Games 2018 Eko. Jurnal Kesehatan Olahraga, [online] 8(1), pp.131-140. Available at: <file:///C:/Users/User/Downloads/fvm939e.pdf>.

Widyastuti, R. A., \& Rosidi, A. (2018). Indeks Massa Tubuh Menurut Umur sebagai Indikator Persen Lemak Tubuh pada Remaja. Jurnal Gizi UNIMUS, 7(2), 32-39. 